\begin{tabular}{|c|c|c|c|}
\hline \multirow{3}{*}{$\begin{array}{r}\text { Case Reports in } \\
\text { Gastroenterology }\end{array}$} & \multirow{2}{*}{\multicolumn{2}{|c|}{ Case Rep Gastroenterol 2019;13:6-11 }} & \multirow[b]{3}{*}{$\begin{array}{l}\text { Karger } \\
\text { Open'access }\end{array}$} \\
\hline & & & \\
\hline & $\begin{array}{l}\text { DOI: 10.1159/000494917 } \\
\text { Published online: January 10, } 2019\end{array}$ & $\begin{array}{l}\text { (c) } 2019 \text { The Author(s) } \\
\text { Published by S. Karger AG, Basel } \\
\text { www.karger.com/crg }\end{array}$ & \\
\hline & $\begin{array}{l}\text { This article is licensed under the } \\
\text { International License (CC BY-NC) } \\
\text { Usage and distribution for commerc }\end{array}$ & $\begin{array}{l}\text { mons Attribution-NonCommercial } 4.0 \\
\text { rger.com/Services/OpenAccessLicense). } \\
\text { quires written permission. }\end{array}$ & \\
\hline
\end{tabular}

\title{
Splenic Injury with Subsequent Pleural Effusion: An Underreported Complication of Colonoscopy
}

\author{
Idrees Suliman John Guirguis Iryna Chyshkevych Nemer F. Dabage \\ Department of Internal Medicine, Blake Medical Center, Bradenton, FL, USA
}

\section{Keywords}

Colorectal cancer $\cdot$ Colonoscopy $\cdot$ Splenic injury

\begin{abstract}
Colorectal cancer is a leading cause of morbidity and mortality worldwide. As such, there are recognized guidelines in the screening of this preventable cancer. There are differences in opinion regarding screening recommendations between the European and United States Cancer Prevention Societies. Screening colonoscopy is an option for routine screening for colorectal cancer in asymptomatic adults. It is a day procedure that is conducted both in hospital and specialized outpatient endoscopy suites. Serious harm is in the region of 3 per 1,000 examinations [Am J Gastroenterol. 2016 Aug;111(8):1092-101]. Splenic injury is a rare complication of colonoscopy whose frequency is unclear. Conservative management of splenic injury is desirable in order to preserve immunocompetence. We present a case in which a previously healthy 59-year-old female developed a splenic injury and later pleural effusion after screening colonoscopy.

(c) 2019 The Author(s)

Published by S. Karger AG, Basel
\end{abstract}

\section{Introduction}

Colorectal cancer (CRC) is a common illness that has worldwide implications. It is currently the third most commonly diagnosed cancer in men and the second most commonly diagnosed cancer in females globally [1]. This accounts for around 1.5 million new cases 
resulting in approximately 800,000 deaths per year [2]. There is a global variance in the incidence of CRC with the highest rates reported in North America, Europe, Australia, and New Zealand. It is postulated that this difference can be accounted by both genetic and environmental factors such as diet and exercise. Additional risk factors for CRC include low socioeconomic status, physical inactivity, smoking, and obesity [3-5].

The aim of CRC screening is to identify premalignant states and possibly prevent future cases of invasive CRC. Currently available measures include stool studies such as guaiac fecal occult blood (gFOBT), fecal immunohistochemistry tests (FIT), fecal DNA tests, and combinations of both FIT and DNA (FIT-DNA). Imaging studies include CT colonography. Direct visualization is only possible with invasive sigmoidoscopy or colonoscopy. Direct visualization with an endoscope has the advantage of being possibly preventive of eventual CRC. This is accomplished by resecting premalignant and high-grade adenomas. There are varying guidelines regarding CRC in different parts of the world for patients of average risk for CRC.

The options supported by the United States Preventative Task Force (USPTF) include colonoscopy, FIT, CT colonography, and gFOBT. They recommend individualizing testing based on preference, comorbidities, and local expertise. However, colonoscopy remains a recommended option for asymptomatic individuals of average risk [6]. By contrast, while colonoscopy is an option, the current European Colorectal Screening Guidelines Work Group [7] from 2013 recommend stool studies such as FIT and gFOBT as first line. They went on to acknowledge the relative lack of evidence as colonoscopy alone as an effective CRC screening intervention.

Screening colonoscopy is a day procedure that is conducted both in hospital and in specialized outpatient endoscopy suites. Serious harm is in the region of 3 per 1,000 examinations [8]. More commonly reported complications include bowel perforation, postpolypectomy hemorrhage, and risks related to sedation. Splenic injury is a rare complication of colonoscopy whose frequency is unclear.

Splenic injury with hemorrhage is a potentially life-threatening condition whose treatment has traditionally been emergent splenectomy. Spleen preserving nonoperative and salvage techniques are attractive to avoid postsplenectomy sepsis, surgical complications/risk, and early infections in the postoperative period $[9,10]$. Splenic injury after colonoscopy was first reported in 1974 [11] and is rare but likely underreported. Splenic injury/hematoma have been associated with pleural effusion [12]; however, the frequency is not clearly defined. Recurrence is possible but resolves after elective splenectomy [12].

We present a case in which a previously healthy 59-year-old female of average risk for CRC developed a splenic injury and later pleural effusion after screening colonoscopy.

\section{Case Report}

A 59-year-old female underwent screening colonoscopy one morning after an uneventful bowel preparation. Her past medical history included osteoarthritis, gastrointestinal reflux disease, obesity, and cholelithiasis. Her past surgical history was significant for remote cholecystectomy, two caesarian sections, and hysterectomy. Medications included estrogen, omeprazole, and ibuprofen. She tolerated the procedure well and was told by verbal report that there were no adenomas detected. She was discharged from the endoscopy suite feeling well.

Approximately $3 \mathrm{~h}$ after the colonoscopy, she developed gradual onset but progressively worsening left upper quadrant pain. The pain was described as sharp and radiated to her left 
shoulder. It progressively worsened throughout the day. Her family called the Emergency Medical Services when the pain had a severity of $10 / 10$ and she developed dizziness with lightheadedness.

On arrival to the emergency room (ER), her vital signs were significant for hypotension (HR 75, RR 16 100\% RA, BP 73/38, T 36.4); however, this resolved after $2 \mathrm{~L}$ of intravenous fluid bolus (111/87). Initial investigations were significant for a $\mathrm{Hb}$ of $10.1 \mathrm{~g} / \mathrm{dL}$ and contrast CT of abdomen and pelvis was significant for a 4-cm perisplenic hematoma (Fig. 1) with midline shift and acute blood surrounding the spleen. There was no extravasation of arterial blood noted. The decision was made to pursue conservative management with pain control and serial $\mathrm{Hb}$ measurements every $4 \mathrm{~h}$. Over the first 2 days, her $\mathrm{Hb}$ gradually trended down but did not fall below $8 \mathrm{mg} / \mathrm{dL}$. On day 3 of admission/after colonoscopy, she required a single unit of $\mathrm{PRBC}$ as her $\mathrm{Hb}$ fell to $7.3 \mathrm{~g} / \mathrm{dL}$. Posttransfusion $\mathrm{Hb}$ remained stable at $9.0 \mathrm{~g} / \mathrm{dL}$; however, she remained in the hospital for a further 4 days for observation, serial $\mathrm{Hb}$ measurements, and pain control. She was discharged home feeling well on day 7.

She presented back to Blake Medical Center 1 month after her discharge. Since leaving the hospital, she had developed gradually worsening exertional shortness of breath and left sided chest pain. The chest pain started approximately 2 weeks after her discharge. It was described as a gradual onset but constant, sharp, pleuritic, nonradiating, and graded as 4/10 in severity. There were no other aggravating or relieving factors. The shortness of breath was also insidious in onset with gradual initial symptoms only present on moderate exertion. She became concerned and decided to present to the ER when she became short of breath on minimal exertion (walking $3 \mathrm{~m}$ ).

On arrival to the ER, her vitals were within normal limits; however, she required $2 \mathrm{~L}$ of oxygen by nasal cannula to maintain oxygen saturations above $95 \%$. Initial investigations were significant for complete opacification of the left hemithorax (Fig. 2). CT of the thorax revealed massive low attenuating pleural effusion causing compressive atelectasis. Repeat CT of the abdomen and pelvis showed that the perisplenic hematoma had increased to $8 \times 8 \times 6$ $\mathrm{cm}$ but was otherwise unremarkable and unchanged. Chest tube insertion was undertaken. The fluid satisfied lights criteria and was thought to be an exudate; however, culture, AFB, and cytology were all negative. The chest tube was removed after 3 days and drained a total of $1.35 \mathrm{~L}$ of serous straw-colored fluid. There was no reaccumulation and she was discharge home $24 \mathrm{~h}$ later. For the previous 12 months, there have been no further events.

\section{Discussion}

Screening colonoscopy is a safe outpatient procedure that rarely results in significant morbidity or mortality. The USPSTF recommendations for colon cancer screening include colonoscopy starting at age 50 years and continuing until 75 years. Asymptomatic individuals older than 75 years should be evaluated on a case-by-case basis. The European guidelines differ in that, while colonoscopy alone is an option, the recommendation is to start with stool studies. Complications directly related to colonoscopy include bleeding after polypectomy, perforation, and infection. These are more common in patients of advanced age and comorbidities [13].

Splenic injury after colonoscopy is a rare but likely underreported complication of colonoscopy. Reviewing PubMed and MEDLINE yielded 174 cases between 1974 and 2018 globally. Risk factors for iatrogenic splenic injury include splenomegaly, previous abdominal surgeries, malignancy, diverticulitis, and peripheral artery disease $[14,15]$. Potential mechanisms 
include excess traction on the splenocolic ligament $[16,17]$, rupture of splenocolic adhesions [18], and direct trauma to the spleen [17].

Pleural effusion post blunt injury to the spleen is a known complication whose incidence is not clearly defined. With the increasing prevalence of spleen sparing interventions [19-22] for splenic injury symptomatic pleural effusion may become more common and should be considered. Being that re-accumulation has been described in the literature, these patients need close follow-up after standard management and investigation for pleural effusion.

Differentiating potentially serious complications of colonoscopy from expected abdominal pain related to insufflation of air can be difficult. Patients with Kehr's sign, which consists of LUQ, left chest, or left shoulder pain that is pleuritic, should be investigated for splenic injury. Splenic injury should be considered in the differential diagnosis in high-risk patients with post colonoscopy abdominal pain as this condition may require emergent intervention.

This case brings to light that while colonoscopy is a well-tolerated procedure, it remains an invasive option that can occasionally be associated with significant morbidity. The advantage of stool testing is that they are noninvasive and a negative result could preclude colonoscopy. Disadvantages of this approach include being unable to directly address premalignant adenomas. With the growing availability and decreasing cost of combined FIT-DNA testing, they have the potential to be the preferred initial testing modality in previously asymptomatic patients of average CRC risk.

\section{Statement of Ethics}

Informed consent was obtained from the patient to use her case for publication.

\section{Disclosure Statement}

The authors have no conflicts of interest to declare.

\section{Funding Sources}

The authors have no funding sources to declare.

\section{Author Contributions}

I. Suliman and J. Guirguis were involved in the literature review and creation of the manuscript. N.F. Dabage and I. Chyshkevych were involved with editing the manuscript.

\section{References}

1 IARC. Lyon: IARC; 2012. Cancer Fact Sheets: Colorectal Cancer. [cited April 7, 2017]. Global Cancer Observatory [Internet] Available from: http://gco.iarc.fr/today/data/pdf/fact-sheets/cancers/cancer-factsheets-6.pdf.

2 Global Burden of Disease Cancer Collaboration. Global, Regional, and National Cancer Incidence, Mortality, Years of Life Lost, Years Lived With Disability, and Disability-Adjusted Life-years for 32 Cancer Groups, 1990 to 2015. A Systematic Analysis for the Global Burden of Disease Study. JAMA Oncol. 2017;3(4):524-48. 


\section{Case Reports in Gastroenterology}

3 Doubeni CA, Laiyemo AO, Major JM, Schootman M, Lian M, Park Y, et al. Socioeconomic status and the risk of colorectal cancer: an analysis of more than a half million adults in the National Institutes of Health-AARP Diet and Health Study. Cancer. 2012 Jul;118(14):3636-44.

4 Willett WC. Diet and cancer: an evolving picture. JAMA. 2005 Jan;293(2):233-4.

5 Doubeni CA, Major JM, Laiyemo AO, Schootman M, Zauber AG, Hollenbeck AR, et al. Contribution of behavioral risk factors and obesity to socioeconomic differences in colorectal cancer incidence. J Natl Cancer Inst. 2012 Sep;104(18):1353-62.

6 US Preventive Services Task Force, Bibbins-Domingo K, Grossman DC, Curry SJ, Davidson KW, Epling JW Jr García FAR, Gillman MW, Harper DM, Kemper AR, Krist AH, Kurth AE, Landefeld CS, Mangione CM, Owens DK, Phillips WR, Phipps MG, Pignone MP, Siu AL. Screening for Colorectal Cancer: US Preventive Services Task Force Recommendation Statement. JAMA. 2016 Jun;315(23):2564-75.

7 von Karsa L, Patnick J, Segnan N, Atkin W, Halloran S, Lansdorp-Vogelaar I, et al.; European Colorectal Cancer Screening Guidelines Working Group. European guidelines for quality assurance in colorectal cancer screening and diagnosis: overview and introduction to the full supplement publication. Endoscopy. 2013;45(1):51-9.

8 Reumkens A, Rondagh EJ, Bakker CM, Winkens B, Masclee AA, Sanduleanu S. Post-Colonoscopy Complications: A Systematic Review, Time Trends, and Meta-Analysis of Population-Based Studies. Am J Gastroenterol. 2016 Aug;111(8):1092-101.

9 Stassen NA, Bhullar I, Cheng JD, Crandall M, Friese R, Guillamondegui O, Jawa R, Maung A, Rohs TJ Jr, Sangosanya A, Schuster K, Seamon M, Tchorz KM, Zarzuar BL, Kerwin AJ; Eastern Association for the Surgery of Trauma. Nonoperative management of blunt hepatic injury: an Eastern Association for the Surgery of Trauma practice management guideline. J Trauma Acute Care Surg. 2012 Nov;73(5 Suppl 4):S288-93.

10 Demetriades D, Scalea TM, Degiannis E, Barmparas G, Konstantinidis A, Massahis J, et al. Blunt splenic trauma: splenectomy increases early infectious complications: a prospective multicenter study. J Trauma Acute Care Surg. 2012 Jan;72(1):229-34.

11 Wherry DC, Zehner H Jr. Colonoscopy-fiberoptic endoscopic approach to the colon and polypectomy. Med Ann Dist Columbia. 1974 Apr;43(4):189-92.

12 Koehler PR, Jones R. Association of left-sided pleural effusions and splenic hematomas. AJR Am J Roentgenol. 1980 Oct;135(4):851-3.

13 Warren JL, Klabunde CN, Mariotto AB, Meekins A, Topor M, Brown ML, et al. Adverse events after outpatient colonoscopy in the Medicare population. Ann Intern Med. 2009 Jun;150(12):849-57.

14 Cassar K, Munro A. Iatrogenic splenic injury. J R Coll Surg Edinb. 2002 Dec;47(6):731-41

15 Masoomi H, Carmichael JC, Mills S, Ketana N, Dolich MO, Stamos MJ. Predictive factors of splenic injury in colorectal surgery: data from the Nationwide Inpatient Sample, 2006-2008. Arch Surg. 2012 Apr;147(4):324-9.

16 Volchok J, Cohn M. Rare complications following colonoscopy: case reports of splenic rupture and appendicitis. JSLS. 2006 Jan-Mar;10(1):114-6.

17 Ahmed A, Eller PM, Schiffman FJ. Splenic rupture: an unusual complication of colonoscopy. Am J Gastroenterol. 1997 Jul;92(7):1201-4.

18 Gores PF, Simso LA. Splenic injury during colonoscopy. Arch Surg. 1989 Nov;124(11):1342.

19 Stein DM, Scalea TM. Nonoperative management of spleen and liver injuries. J Intensive Care Med. 2006 SepOct;21(5):296-304.

20 Siriratsivawong K, Zenati M, Watson GA, Harbrecht BG. Nonoperative management of blunt splenic trauma in the elderly: does age play a role? Am Surg. 2007 Jun;73(6):585-9.

21 McIntyre LK, Schiff M, Jurkovich GJ. Failure of nonoperative management of splenic injuries: causes and consequences. Arch Surg. 2005 Jun;140(6):563-8.

22 Bhullar IS, Frykberg ER, Siragusa D, Chesire D, Paul J, Tepas JJ 3rd, et al. Selective angiographic embolization of blunt splenic traumatic injuries in adults decreases failure rate of nonoperative management. J Trauma Acute Care Surg. 2012 May;72(5):1127-34. 


\begin{tabular}{l|l}
\hline DOI: 10.1159/000494917 & $\begin{array}{l}\odot 2019 \text { The Author(s). Published by S. Karger AG, Basel } \\
\text { www.karger.com/crg }\end{array}$
\end{tabular}
www.karger.com/crg

Suliman et al:: Splenic Injury with Subsequent Pleural Effusion: An Underreported Complication of Colonoscopy

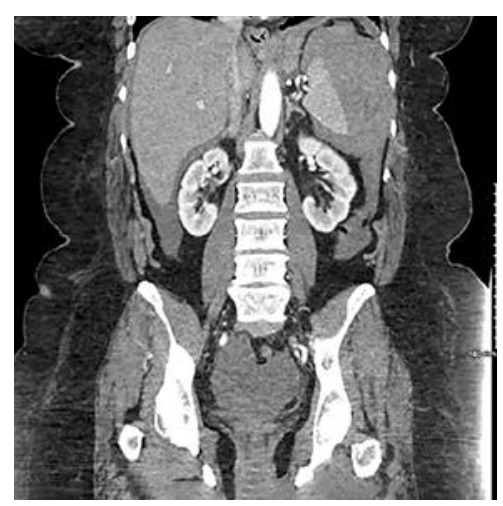

Fig. 1. Coronal view. CT of the abdomen and pelvis showing a perisplenic hematoma.

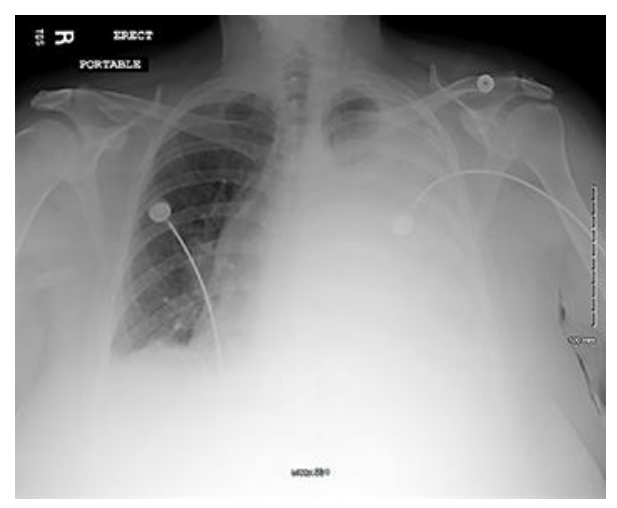

Fig. 2. Portable AP chest X-ray showing near complete opacification of the left hemidiaphragm. 